\title{
The interpretation of the revelatory events in John 17:24-26: An exegetical exercise
}

\author{
D J van der Merwe \\ (Universiteit van Suid-Afrika)
}

\section{ABSTRACT \\ The interpretation of the revelatory events in John 17:24-26: An exegetical exercise}

John 1:18 spells out the purpose of the incarnation of the Son of God (to make God known - ejhgeis qa i) and functions as the transition from the prologue to the rest of the Fourth Gospel. With verse 18 the Evangelist signals that the revelation of God, through his Son, is intrinsic to the composition of the Fourth Gospel. This is particularly evident in chapter 17(:24-26), where we find an explicit reference to a triadic revelation: revelation during Jesus' ministry, post-resurrection revelation, and future eschatological revelation. The aim of the investigation of Jn 17:24-26 is to gain an understanding of what Jesus (and the Fourth Evangelist) tries to emphasize and to communicate to his disciples (and the readers) concerning his revelatory (-salvific) mission. In the exposition of this text it is pointed out what each phase in the triadic revelation comprises, and how these phases of revelation link to one another.

\section{INTRODUCTION}

The Fourth Gospel opens with a hymnic prologue (1:1-18). Verse 18 functions as the transition from the prologue to the rest of the Gospel. This is a move from a programmatic statement about the logos to the concrete embodiment and demonstration in the Gospel narrative of how that logos is manifested and functions, and it begins in 1:19. In verse 18 the Evangelist points to the purpose of the incarnation: to make God known (monogenh," qeo," of wh eif' ton kokpon tou' patro," ekeiño" ejhghsato). The action of Jesus Christ, as the Revealer, is here designated as exhgei s̀ qai (Schnackenburg 1968:279; Bultmann 1971:83). Not one of all the witnesses to God has witnessed like the one who was with God from the beginning and was God (1:1f). He who comes from above is above all and bears witness to all he has seen and heard (3:31). He alone could speak of heavenly things from personal experience (cf $3: 31 f)$. 
It is only in this light that we can understand what the Fourth Gospel says about the coming and work of Jesus Christ (Ridderbos 1997:59). With verse 18 the Fourth Evangelist signals to us that the revelation of God, through his Son, is intrinsic to the composition of the Fourth Gospel ${ }^{1}$ (cf O'Day 1986:33f). This is particularly evident in chapter 17(vv 24-26), where we find an explicit reference to a triadic revelation: revelation during Jesus' ministry, post-resurrection revelation and future eschatological revelation.

The aim of the interpretation of John 17:24-26 is to gain an understanding of what Jesus (and the Fourth Evangelist) tries to emphasize and to communicate to his disciples (and the readers) concerning his revelatory (-salvific) mission. In the exposition of this text it will be pointed out what each event in the triadic revelation comprises and how these phases of revelation link to one another.

In order to determine this, the contextual location of these verses in the micro context of chapter 17 will first be examined to determine the setting in which they have to be interpreted. A discourse analysis will follow to determine the sub-sections of 17:24-26, and how they relate to one another. Subsequently, words relating to Jesus' acts of revelation in these verses will be pointed out and compared with other words in the New Testament and in the Fourth Gospel that relate to or are translated as 'revelation' in order to determine the distinctiveness of these words. Finally, detailed exegesis will be conducted to explain how the revelation brought by and through Jesus is to be interpreted and understood.

\section{THE CONTEXTUAL INTERPRETATION OF 17:24-26}

Chapter 17 can be subdivided into 5 blocks: A (vv 1-8), B (vv 9-16), C (vv 17-19), B' (vv 20-23) and A' (vv 24-26), which form a chiasm. This analysis indicates that verses 24-26 (Block A') form a unit and link with Block A (vv 1-8) (see Van der Merwe 1995:334ff).

Block $A$ : The following words and phrases indicate that Jesus completed his mission: ef hluqen h]wia, nun doxas on me suyt o; elgon teleiwsa" (note the past tense of the verbs being used). In the accomplishment of his task the Son glorified the Father, and will further

1 The revelatory theme is extremely overwhelming throughout the Gospel, therefore Bultmann (1941) wrote his commentary on John from the perspective of revelation. 
glorify Him on the cross. He revealed the Father by giving his followers the words his Father had given him. In the end the disciples believed (knew) that Jesus had been sent by the Father.

Block $A^{\prime}$ : This block looks at the successful missionary work of Christ from both the heavenly ( $\mathrm{v} 24$ ) and the earthly (vv 25, 26) perspectives. The salvation of men also had eschatological implications. Jesus' disciples will be united with him in the 'world above' (v 24), and will see the glory of Jesus from another perspective. Jesus is still involved in this divine mission ( $\mathrm{v} 26$ ). He will continue to make known the Father (and himself) through his presence in his disciples.

These two blocks (A-A') ${ }^{2}$ are concerned with the missionary work of Jesus (cf Schenke 1998:328). His entire revelatory-salvific programme has been spelled out -- he came to reveal the Father as the 'One who sent me'3 and to save the world from sin. Block $A$ is concerned with the past and present, while block A' relates to the future of Jesus' missionary work. In the detailed exegesis it will become evident how the content of Block A will help to clarify the meaning of 'revelation' in Block A'.

\section{A DISCOURSE ANALYSIS OF JOHN 17:24-26}

Now that we have determined the position of verses 24-26 in the microcontext of Ch 17 and the setting within which these verses are to be interpreted, a discourse analysis will be conducted. This will help to

2 Blocks A and A' are related on the following grounds:

(a) Vocabulary: The following words are used significantly in both blocks -egnwkan, doxan, apesteila", pro;katabolh" kosmou, (pro; tou'ton kosmon eithai).

(b) Theologically: Christ is the prominent character in these blocks.

- doxan: In block A, Jesus glorifies the Father and it is indicated that he will himself be glorified.

In block A', reference is also made to Jesus' future glorification. In both blocks Jesus' glorification relates to the glory he enjoyed before the foundation of the earth.

- eg nws a n: In block A, Jesus reveals the Father to his disciples.

In block A', it is stated that Jesus will continue with this revelation.

3 This phrase calls for the agency concept, which figures throughout the Fourth Gospel, but features particularly in chapter 17 . The agency concept constitutes the setting within which chapter 17 is to be interpreted (see Van der Merwe 1995:325ff). 
determine the subsections of these verses, the Evangelist's argument, and how these sections relate to one another.

\section{Linguistic and semantic relations}

The following is a discourse analysis of Block A' (vv 24-26):

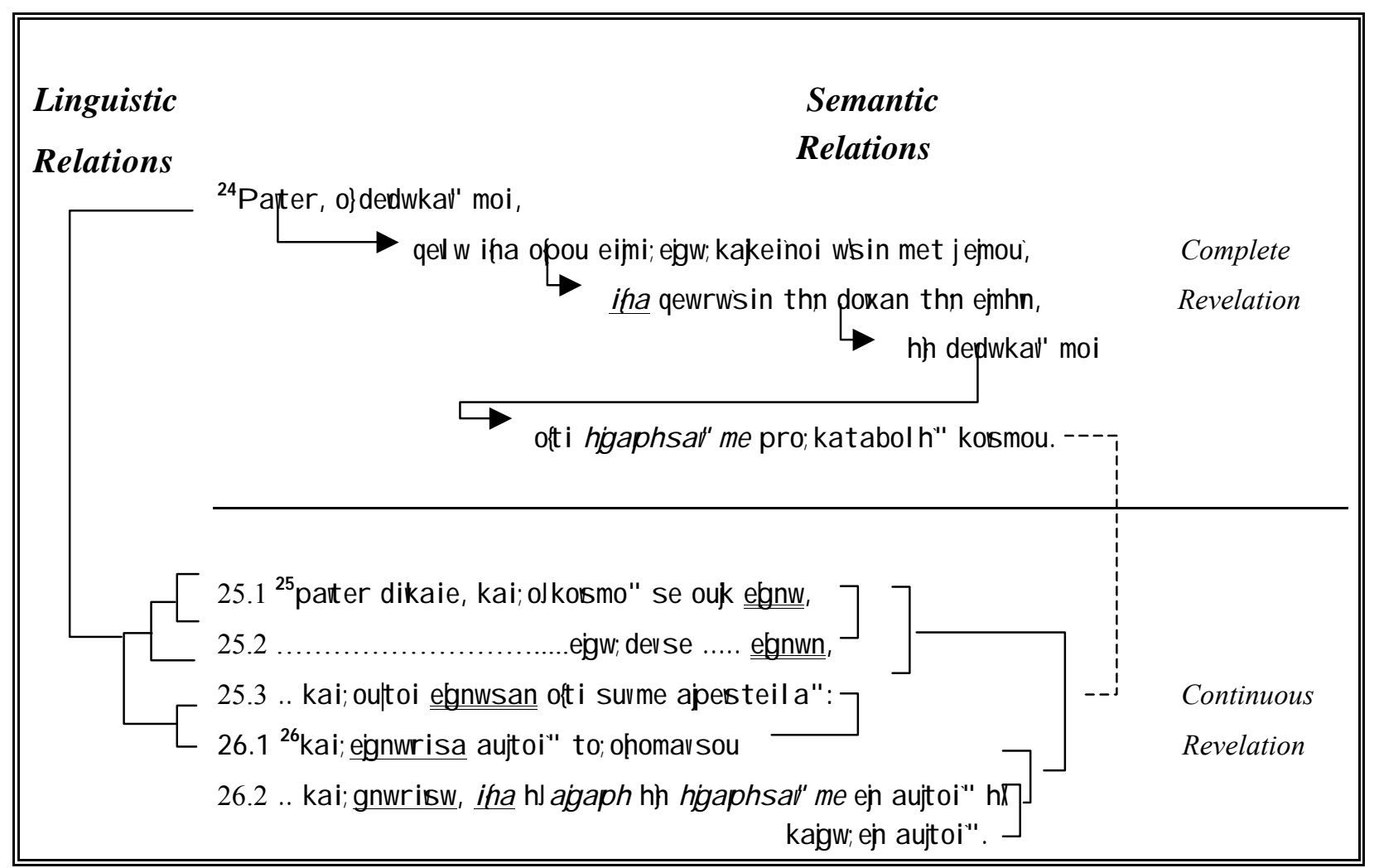

This discourse analysis clearly points out that the content of verse 24 differs from that of verses $25 \mathrm{f}$. The i fa -phrases in both subsections point out the objectives of revelation. The focal point in verse 24 is ina qewr ws in thn doxan thn ejmh, while in verses $25 \mathrm{f}$ it is i fra $h$ Jagaph h hgaphsa"v me ej autoi" hXkagw; (Jesus) ej aut oi "X

The central theme in these verses is "revelation". In verse 24 the revelation concerns the future seeing and experiencing (qewr ws in) of the glory ( $h n$ doxa $n$ ) of Jesus in heaven by his disciples, as it was before his incarnation. The revelation referred to in verses $25 \mathrm{f}$ firstly refers to the revelation during Jesus' ministry and, secondly, concerns a continuous revelation of God, coming from Jesus, who will live in his disciples ( $k a g$ w; en a uf oi " - v 26) on earth through his Spirit (14:17f). This revelation will be realized through teaching (gnwris w ... a uf oi" to; ohoma vs ou). 


\section{Interpreting the sequence of the verses ${ }^{4}$}

Although the event mentioned in verse 24 takes place after that referred to in verses 25f, is it mentioned first to emphasize Jesus' return to the Father's presence, an event the disciples cannot yet comprehend. Another reason for this is so that verses $25 \mathrm{f}$ can be used to describe the manner in which the disciples will be enabled to see Jesus' glory ( $\mathrm{v} 24$ ). This is typical Johannine phenomenon, which also occurs in 17:6-8. Here, for the purpose of emphasis, preference is given to a functional rather than a chronological sequence.

\section{4 “REVELATION" DEFINED}

The above analysis has helped us to determine two different perspectives of Jesus' revelatory acts. The following exercise compares the verbs used in 17:24-26 with other common revelatory words used in the New Testament, and words used elsewhere in the Fourth Gospel. This will help to determine the distinctiveness of these verbs and what the revelatory events in verses 24-26 comprise. The exact semantic meanings of the two revelatory events will become clearer in the next section, where the detailed exegesis will be conducted and the linguistic and literary contexts of each revelatory event be considered.

Lexicographically The Shorter Oxford English Dictionary (1984:1819) defines "revelation" as (1) "The disclosure of knowledge to man by a divine or supernatural agency; (2) Something disclosed or made known by divine or supernatural means; (3) A striking disclosure of something previously unknown or not realized". In Christian theology, "revelation" expresses more in particular the significant self-disclosure of God to man. The Greek language possesses various terms and expressions relevant to this process. A p okal upt w, a compound word from kal upt w (which can be translated as hide, conceal) and a $\mathrm{p} 0$ (from), carries with it the idea of unveiling something previously hidden. $\mathrm{Dhl}$ ow, derived from $\mathrm{dh} \mid \mathrm{O} \sim$ (which means and can be translated as clear, manifest), calls more attention to the goal, i.e. that as a result something becomes known and manifest. Epif aneia suggests a visual appearance, a manifestation of deity. Other relevant concepts include gnwriøw, make known, (also

4 The position of verse 24 in this cluster: One should expect verse 24 to be placed last, for it describes the culmination of salvation. Even verses 25, 26 would be more logically placed following verse 23 . 
ginwskw, knowledge), of ama, an apparition (something seen) and op ta a ia, a vision (Mundle 1978:309f).

In the Fourth Gospel words most commonly translated as "revelation" are the adverb fanerw $(7: 4,10)$ and the related verb f a ner ow $(1: 31 ; 2: 11 ; 3: 21 ; 9: 3 ; 17: 6 ; 21: 1,14)$. In $1: 18$ ejhghsat 0 is used, in 12:38 a pekal uf qh, and in 14:21, 22 emf anisw. None of these words occur in 17:24-26. Semantically speaking, other words, phrases or events could also be used to describe an event of revelation as we will find in 17:24.

In 17:24-26 the Fourth Evangelist uses the following two verbs to describe the two different kinds of revelation: the unusual verb qewr ew $(\mathrm{v}$ 24 ) and the commonly used verb gnwrigw (v 26). Lexicographically Danker (2000:203) defines gnwrizw (v 26) as 'to cause information to become known: make known, reveal a name'. Louw and Nida (1988:337), in their semantic Greek-English Lexicon, agree with Danker and define it similar as "to cause information to be known by someone - "to make known".

The revelatory event mentioned in 17:24 (qewr ew) differs from the one in verse 26 ( $g$ nwr $i \sharp \mathrm{W})$. This event concerns the seeing of Jesus' glory in heaven ${ }^{5}$. Danker (2000:454) defines qewr ew (v 24) as 'the spiritual perception of the one sent by God which is poss. only to the believer', whereas Louw and Nida $(1988: 279)$ define it as 'to observe something with continuity and attention, often with the implication that what is observed is something unusual'.

Hence, from 17:24-26, it is clear that two kinds of revelation occur. Verse 24 spells out an event where the disciples will see Jesus' heavenly glory, while verse 26 refers to Jesus' act of revelation in making known the Father's name. The revelation act in verse 26 concerns the communication of information (making known the name of the Father), while in verse 24 it concerns an experience (seeing the glory of Jesus). John 17:24-26 informs us that the act of communication of information (teaching) in verse 26 is a prerequisite and essential to the actualization of the experience in verse 24 . In verse 24 Jesus is the object of revelation,

5 Gnwri $\mathbf{z w}$ occurs only once more in the Fourth Gospel i.e. 15:15 while qewrew occurs 22 times and four of these occurrences $(2: 23,4: 19,12: 45$ and 14:17) refer to a spiritual understanding. 
while in verse 26 he is the subject (medium) of revelation and God is the object. What these two forms of revelation comprise will now more closely be determined through detailed exegesis.

\section{DETAIL EXEGESIS}

\section{Verse 24}

Verse 24 portrays Jesus after his return to the Father with the ipsissima gloria. The ultimate goal has been reached. The ultimate fulfilment of Jesus' mission occurs when he is back in the thn doxan of the Father (doxa which he possessed with the Father pro; t ou't on kos mon einai, v $5)$, surrounded by his disciples who can now see his doxa, requested from his Father in 17:5. Jesus addresses the Father (v 24) to express his desire and his will (qelww). He wants his disciples to behold his glory ${ }^{6}$.

The doxa that Jesus has already given his disciples during his ministry (v 22), is only portional and temporary, but an anticipation of the full doxa, which consists of participation in Jesus' revealed doxa (cf. Bultmann 1941:398; Schnackenburg 1975:223) ${ }^{7}$. This is indicated by the i fina-particle. This doxa of Jesus was revealed during his active existence on earth, which his disciples beheld (egea s a meqa -- 1:14), but only in faith (see $2: 11 ; 11: 40$ ). To see (qewr ws in, v 24) this doxa of Jesus, which he experienced before the foundation of the world $(17: 5)^{8}$, the disciples are to be "with him", that is, together with him "where he is himself"'. The Johannine community lives in this expectation, because they have already experienced the revelation of the love of the Father (v 26) (Schnackenburg 1975:223). To be "with" Jesus where he is, is different from his being "in" them (cf. vv 21-23). Thus the doxa in verse 24 is different from that in $1: 14$, but the same as that referred to in 17:5. This doxa ( $v$ 24) is freed from the veil of the doxa, which Jesus had on earth. According to 12:26 (ejn ejmoivti" diakonhl ejnoi; akol ougeituw, kai; opou eimi; ejw; ekei"

6 Although these final verses relate to Jesus' present disciples, his future disciples are not excluded (see v 25).

7 The reason why Jesus refers to this doxa as $\mathrm{t} h n$ doxan thn ejmh $n$, is because this doxa is assigned to him $(1: 14)$. He possessed this doxa from eternity, pro;

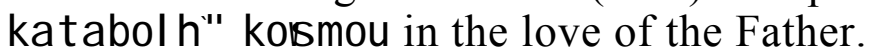

$8 \quad$ Cf Mt 13:35; 25:34; Eph 1:4; Heb 4:3; 1 Pet :20; Rev 13:8; 17:8.

9 This expression of "place" also appears in 12:26 and 14:3, and is used by the Fourth Evangelist to describe the union of the disciples with Jesus in heaven. 
kai;oldiakono" ol ejno," estai: eja ti" ejmoi; diakonh/timhsei aut on of pathr), the disciples of Jesus will, by implication, share in this doxa (Bultmann 1941:398).

Jesus' disciples, who followed him during his earthly ministry, could testify that they had seen the glory of Jesus $(1: 14)$. Christians throughout history could only glimpse something of Jesus' glory (cf 2 Cor 3:18). But one day they shall see him as he is (1 Jn 3:2). Then the glory that all of his followers will see will be his glory as God, the glory he enjoyed before his mission, majesty and greatness (see Van der Merwe 2002:226ff; cf. also Köstenberger 1998:48). It seems as if those who share with the Son the privilege of being loved by the Father (v 23), also share in the glory to which the Son is restored in consequence of his death/exaltation. Here the Fourth Evangelist moves to the future eschatology of 14:2-3 (Carson 1991:569f).

Verse 24 reflects the definite future fulfilment of discipleship ${ }^{10}$. The petition of verse 24 is based on the realization of the events spelled out in verse 26. This Johannine view is a mature reflection of the essence of Christian hope and should help us to understand the idea of fulfilment and consummation (Schnackenburg 1975:223f; cf Barrett 1978:514; Newman \& Nida 1980:545). Only when a follower of Jesus is obedient to Jesus' commission (of discipleship), can he expect one day to experience the doxa of Jesus (cf 12:26). With this expectation in mind, the disciples can fulfil the mission of Jesus. This statement by Jesus (op ou eijmi; eg w; kakeinoi w\$in met jemou) contemplates the time of his pronouncement to Peter in 13:33, 36, namely that he will follow Jesus at a later stage (Barrett 1978:514).

This "glory" of Jesus, characterized as pro; t ou't on kos mon ei ha i (v 5) and op ou eijmi ; eg w; (v 24), can be referred to as Gloria in Excelsus and relates to Revelatio in Excelsus. Glory and revelation conjoin in the Fourth Gospel (see $1: 14 ; 2: 11 ; 11: 4 ; 17: 1-5$ ). This "glory" of Jesus in heaven (opou eijmi; egw; - v 24) will be seen (i ka gewrws̀in) and experienced (cf Schenke 1998:328) by the disciples as something different and new. It is a Revelatio in Excelsus, because through this glory of Jesus

10 Although this idea is close to the Gnostic idea of the "ascent of the soul", the Johannine text differs from those of the Gnostics through the believer's personal bond with Jesus, in whose glory believers are to share (Schnackenburg 1975:223f). 
his disciples will also see and experience the "glory" (majesty and greatness) of God. Who has seen, heard and experienced Jesus, has seen, heard and experienced God. The revelation of God occurs through the revelation of Jesus (14:9-11).

\section{Verses 25-26 (These verses describe how the Revelation in Excelsus will be realized)}

After providing this prospect of the ultimate goal, which lies ahead in the heavenly sphere, the prayer (re)turns to the eschatological time in the earthly sphere, the situation of the community. Jesus will continue his divine revelatory-salvific mission through his disciples (kai; egnwris a a uf $0 \mathrm{i}$ " t 0;0homa vs ou, v 26; cf. vv 6,8), but in a different mode (kag w; ej a uf $0 \mathrm{i}^{\mathrm{I}}, \mathrm{v} 26$ ), as expressed in verses $25 \mathrm{f}$. The content of these verses can be presented as follows:

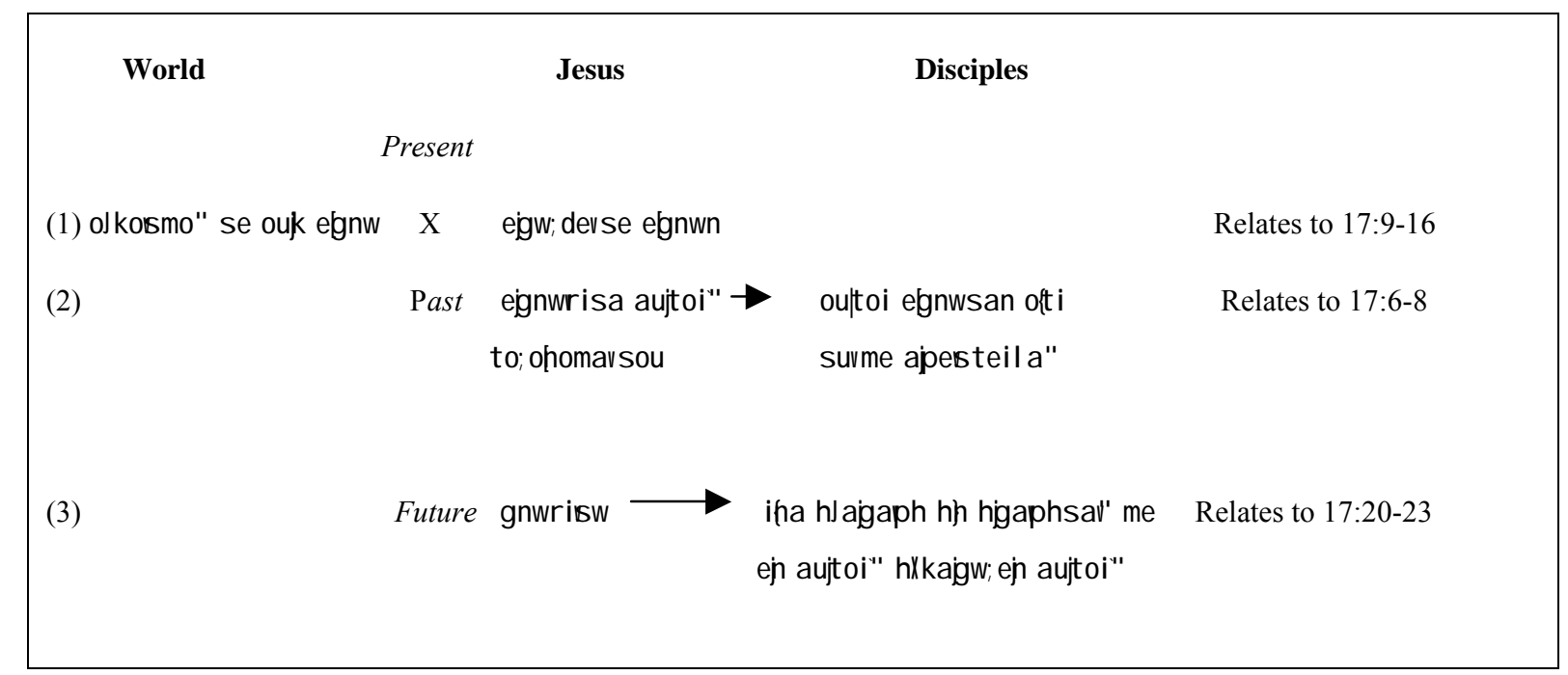

These two verses $(25,26)$ can be grouped into three units determined by the "knowledge" of Jesus and his revelation. The first unit (1) forms an antithetic parallelism. Here (v 25) the difference between Jesus and the world concerning their knowledge of God is evident (cf Malatesta 1971:209) and is expressed as a reality in the present: 


\section{25.1 kai;0Jkosmo" se ouk egnw ${ }^{11}$ \\ V 25.2 eg widev........ se ..... egnwn}

The second unit is composed of two parallel aorist clauses which refer to Jesus' past divine revelation and his discisple's response to it. Since the first (v 25.3) affirms what the disciples have recognised, the second (v 26.1) explains the basis of the disciple's knowledge: Jesus has made known (revealed) to them the 'name of the Father' (see also 17.6) (cf Malatesta 1971:209):

V25.3 kai; outoi egnwsan ołi suv me apesteila"12

V 26.1 kai;........ egnwris a a ut oi" t o;ohomavs ou

The third unit (v 26.2), which begins with kai; gnwrisw, envisages a future revelatory act by Jesus and the outcome thereof. The love of God, which means God himself (1 John 4:8,16) and Jesus will live in the disciples (14:23). This last unit contains the climax of verses 25-26. The ultimate goal of the revelation of the Father's name to the disciples is expressed by the ina-clause, which contains two phrases to form a symmetric parallelism (cf Malatesta 1971:209):

$$
\begin{aligned}
& \text { V } 26.2 \text { ina hJagaph highaphav me en a ut oi" hX } \\
& \text { V } 26.2 \text {.......kagw; .................... en aut oi" }
\end{aligned}
$$

The first unit describes the situation: the world does not know the Father, but Jesus does. The second unit describes the solution to this situation. Jesus has revealed the Father to a group of people (his disciples), who now know that he has sent Jesus who, by implication, has to reveal the Father to the world. In order to accomplish this, the third unit indicates that Jesus will continue his mission of revelation in the world and to the world through the lives of his disciples. But this revelation was also meant to

11 In verse 11 Jesus addresses the Father as pater a ie, while in verse 25 he addresses him as pater dikaie. Both the OT (Jer 12:1; Ps 119:37) and the NT (Rom 3:26) speak of God as "righteous", because God does what is right. This is seen when he punishes sinners and saves those who accept Jesus as their saviour (1:12f). The term a ie was probably chosen by the Fourth Evangelist because the idea of judgment is implicitly present in the statement that ol kor mo" se ouk egnw (v 25) (Brown 1972:779; Newman \& Nida 1980:545f).

12 Verse 25.3 also contrasts with verse 25.1. The disciples know (gnwsan), whereas the world lacks understanding (ouk egnw). 
enable the disciples to move to a higher level of faith (to believe also that Jesus ascended to the 'world above').

The focus in verse 25 is on the disciples. The reference to the cosmos has no value and meaning in itself, but by relating it to the disciples by means of $k a i ; \ldots k a i$; a contrast is created. Nothing more is said about the cosmos, while more is said about the disciples. They now know that the Father has sent Jesus $(17: 8,25)^{13}$ (Schnackenburg 1975:224), but they do not know the Father as Jesus does. While the world does not know God, it is stated that Jesus knows God. A unique reciprocal knowledge exists between the Father and the Son. From eternity the Son has been in the bosom of the Father $(1: 1,18)$. Thus the disciples' knowledge of God is mediated (revealed) through Jesus (Barrett 1978:515).

In verse 26.1 Jesus refers to his past ministry, when he had made known the Father's name to his disciples. But already in 17:6 and 8 the Son's task of revelation is phrased in terms of ef a nerws a vs ou t 0;0homa (v 6; see also vv 2, 9, 12, 24) and ta; rhmat a a \{elpwk $\nleftarrow$ moi dedwka a uf oi (v 8). The phrase t a; rh mat a ... is found in a similar form in 17:14, but in this case ton logon is used. The phrase ef a nerws a $v^{14}$ sou t 0 ; ohoma, is found once again in a similar form in 17:26, but differs somewhat in that the verb gnwrigein is used ${ }^{15}$ to bring out the full meaning of revelation. The different verbs used here by the Fourth Evangelist reflect different perspectives with regard to the same revelatory

13 Verse 25, egw; devs e egnwn is introduced here because it is through Jesus' knowledge of the Father that they could gain knowledge of God and turn towards him (Schnackenburg 1975:224).

14 The verb ef a nerws a voccurs elsewhere as a term of revelation in terms of the manifestation of Jesus $(1: 31 ; 7: 4)$, his glory (2:11), and the works of God (9.3). According to Lenski (1961:1128f), 'The aorist records the accomplished fact while the verb faneroun is comprehensive, "make visible and clear", ... somewhat like "to reveal" by all that Jesus is, says, and does'. Barrett (1978:505) and Carson (1991:558) agree with Lenski; the aorist, ef a nerws a y sums up the work of the ministry of Jesus. According to Carson it also includes the cross. Danker (2000:1048) agrees that it refers to the 'make known' through Jesus' teaching, accompanied by a revelation that comes through a deed.

15 Schnackenburg (1988:196) refers to egnwrisa in verse 26 as a revelatory term that is also encountered in 15:15, where Jesus, within the context of friendship, says of i pant a a hhkous a para; t ou'patrou mou egnwris a umin. In 16:25 Jesus declares his intention to make the Father's name known. 
event in the time of Jesus and the Paraclete. The revelation of the Father becomes clearer when these four references are compared:

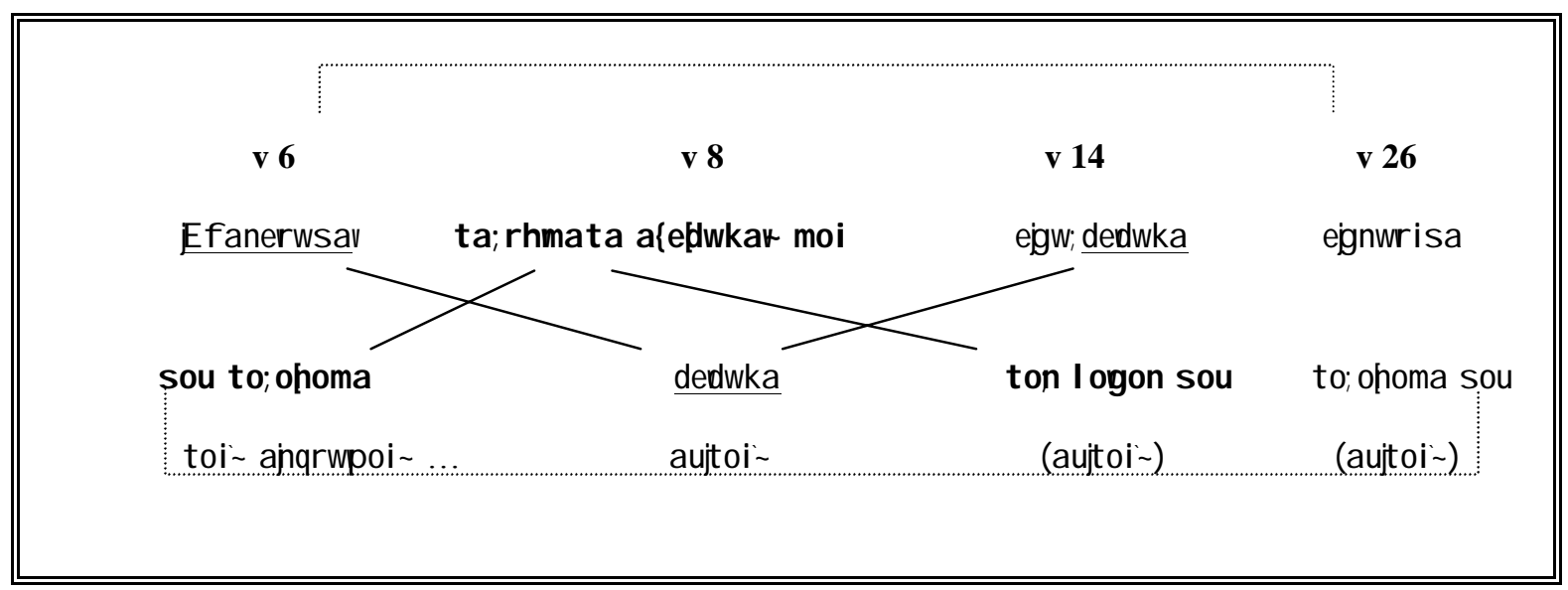

The chiasms and parallelisms in the above comparison emphasize the close connection between t 0; 0homa (vv 6, 26) and t a; rhmat a (v 8; t on logon sou, v 14). Even the verb didomai (v 8 and v 14) is used in a similar way as f a neroun ( $v$ 6) to throw light on the fact that Jesus has given his disciples $t a ; r h m a t a$, given to him by the Father. Whereas the verbs ef a nerws a, dedwka and egnwris a indicate the act of revelation (by Jesus), the phrases s ou t o; ohoma, $t a ; r h m a t ~ a ~ a ~\{e \not l w k a \forall$ moi and t on logon sou indicate the content of the revelation (by Jesus). Thus all the above references refer to the revelation of God that comes through Jesus (Newman \& Nida 1980:531; also Wilckens 1998:263).

But what does the Fourth Evangelist mean with the expression t 0; ohoma sou? According to the expressions in 17:11, 12 and 26, the interpretation of the phrase in verse 6 goes beyond the literal. For the Fourth Evangelist t $0 ; 0$ homa ${ }^{16}$ is nothing other than the revelation ( $\mathrm{a}$; rhmat a / t on I ogon) by which Jesus makes God knowable ${ }^{17}$. To manifest

16 For the Semites a name was the expression of a person's character and power. Hence, making known God's name to the disciples, would mean to reveal the character and power of God to them. This revelation took place through the person, words and works of Jesus. Bultmann (1941:381) rightly observes that in Jesus' work, God himself is at work, in him God himself is encountered.

17 Newman and Nida (1980:530) maintain that the reference to t 0; 0homa of God is another way of referring to God directly. According to Schnackenburg (1975:199, Bernard 1963:564, Morris 1975:723 and Dodd 1980:96), t 0; ohoma sou refers to God's being and nature (also see 12:28, and especially 17:11), his 
the name of the Father, is to manifest the Father himself (v 6), just as to make known the name of God is to reveal God (v 26) (Malina \& Rohrbauch 1998:247). In accepting the words of God, the disciples acknowledge the content as the revelation of God in Jesus (Schnelle 1998a:256).

Hence, when Jesus then says "Efanerwsavsou to; ohoma / egnwris a a uf oi" t 0;0homa vs ou", the intention is to convey that he gave to his disciples 'all the information that they needed to know God' (cf $3: 16,17 ; 4: 34 ; 6: 38 f ; 12: 49$ f and 5:36f for other examples of Jesus' acts of revelation). This is shown by the parallel between al hqeia in verse 17, crhmat a in verse 8, and log o in verse 14 (Bultmann 1941:385).

Through these events of revelation Jesus brought the 'above' into the 'below'. He did this without becoming part of the 'below'. Because the Johannine dualism also concerns a person-dualism, which resides in the qualities of the person, it becomes possible for Jesus to act on earth without becoming qualitatively part of the mundane (cf Van der Watt 1991:108). Therefore, it can be stated that Jesus' words are always God's words (5:19-30), he bears the name of God (e $\mathrm{g} 17: 6,11,12,26)$ (Thompson 2001:123) and is himself the self-expression of God. Jesus keeps the word of God (8:55), his commands (15:10), and encourages his followers to observe his word $(8: 51,52 ; 14: 23)$, or words $(14: 24)$, and his commands $(14: 15,21 ; 15: 10)$. The fact that ef a nerws av(v 6) / egnwris a (v 26) is in the aorist, sums up the total revelation of God in the ministry of Jesus (Newman \& Nida 1980:530). His incarnation, his teaching, his miracle-working, his encounters with people, and indeed his entire life, are placed within the all-embracing context of revelation. 'As the narrative of

holiness, righteousness and love (the disclosure of God himself, which is the disclosure of the al hqei a -- Bultmann 1941:381; cf Lenski 1961:1129), which are certainly expressed in the address to the Father and the attributes connected with his name. Sanders \& Martin (1975:369), Carson (1991:558) and Lindars (1981:521) maintain that the aforementioned refers to the character and person of God, which were proclaimed throughout the ministry of Jesus and included even the cross. This description of God's character and person was given to Jesus by God himself (v 8; also 12:50). Schenke (1998:324) epitomizes the above statements about the meaning of t 0 ; ohoma s ou beautifully in 'Mit seinem Namen tritt der unbekannte Gott (vgl. 1,18; 4,22; 5,37; 8,19) aus der Verborgenheit (Ex 3,13ff; Jes 52,6; Ez 39,7) hervor; er erschließt sich und wird zugänglich. ... In Jesus hat sich Gott irdisch gezeigt $(1,14 ; 8,19 ; 10,30.38 ; 14,7-10)$ und als der "einzige, wahre Gott erkennen" lassen $(17,3)$ '. 
the Gospel proceeds, the revelatory path of the Logos among human beings is developed and the saving significance of Jesus Christ is reflected upon' (Schnelle 1998b:510). Through all this he brings to mankind the distant and totally other God. He is the visible manifestation of the invisible God, the only way to the Father. As Medium he is both the Bringer and Content of the revelation (Schwankl 1995:372). Thus, in Jesus' work, his ministry, God himself is at work, in him God himself is encountered (Bultmann 1941:381).

Verse 26 intensifies the revelation. The earthly course that Jesus' disciples (in general) have to follow towards their fulfilment will take them through an even deeper revelation of God's being $(16: 12)^{18}$. They will experience an even more powerful inclusion in communion with God, who will disclose himself to them and will accept them more and more into his love ${ }^{19}$. The heavenly goal includes an inner growth on the part of the disciples while they are still in this world (Schnackenburg 1975:224f). In the end 'the disciples should love others in the same way that God has loved Jesus' (Newman \& Nida 1980:546). Through this love God would be revealed to the world (17:20-23).

The apparent contradiction -- that Jesus will make known (v 26.2 gnwrisw) as a further revelation to his disciples - cannot be explained only in terms of the dialectic tension which exists in the Johannine theology concerning Jesus' revelation of himself, while he was physically with his disciples on earth, and the continuing revelation of the Paraclete, who will remind them of Jesus' teaching (14:25f) (Schnackenburg 1975:224f). Although the Paraclete is not mentioned at all in this prayer,

18 Although the names pater (v 24) and pater dikaie (v 25) are used, God's name ( $\mathrm{v} 26)$ cannot be restricted simply to the name 'Father'. According to Schnackenburg $(1975: 225)$ it points rather to the good and holy being of the Father. The fact is that, through Jesus' revelation of this name and the receiving of this name among believers, the divine being of God is implanted in the disciples. This therefore means that the love of God, the love with which he loves his Son, 'is also present in them, dwells in them and continues to have effect in them'. This love, which proceeds from God, is the bond that unites the Father and his Son. It also unites the Father and his Son with the believers (14:23).

19 The repeated $\mathrm{kai}$; in verse 26 forms the connection between egnwris a and gnwrisw. This should then indicate progress from a previously experienced revelation of the name of God (egnwrisa a ut oi" to; ohomavsou) to further revelations. 
Jesus declares his intention to continue (gnwris w - v 26) to make the name of the Father known ${ }^{20}$ (cf 16:25; 17:6,8) ${ }^{21}$. The heavenly Jesus will do this through the Paraclete through whom he continues to be present among his disciples (and the readers) (14:15-18, 26; 15:26f; 16:5-14). ${ }^{22}$ Continuous revelation has to take place also to facilitate the continuity of Jesus' mission and so that Jesus' disciples can also believe that he has gone back to his Father (cf Nicholson 1983:63ff).

But, considering the context of this entire chapter, t 0; o homa s ou not only refers to the character and person of God, but also defines implicitly the way of life that ought to characterize the lives of the disciples who perceive the revelation of God by the Son of God. Knowing God implies that God lives in the disciples, and that their way of life should correspond with the character of God. It also relates to the mission to which they have been appointed by Jesus. This is the content of the revelation that Jesus himself received from God and communicated to his disciples through his life, words and deeds (v 8).

The two 'codes' that the Fourth Evangelist uses to indicate this reality are the continuing revelation of the name of God (v 26; see also vv 6 and 11f), and the mediation of the love of God. 'Both are intimately connected with each other and closely interrelated.' Because of the presence of the Paraclete the disciples will now be able to say [de nun en parrhsia/lalei" kai;paroimian oudemian legei" (16:29). Bultmann (1941:400) points out that in this case, the future 'making known' (gnwrisw, v 26) is only possible on the basis of the past revelation (egnwrisa - v 26), and the past (egnwrisa) only becomes significant when it is continued by a future revelation ( $g n w r i s w)$. With and in this knowledge God bestows his love on his own, the followers of Jesus: i fra hJagaph hi higahsav" me ej a ut oi" hXkagw; ej a ut oi" (26.2). The experience of this love of God now becomes the determining power in the

20 The following is a comparison between 1:18 and 17:26 which forms a chiasm:

$$
\begin{aligned}
& 1: 18 \text { ekeiño ............... exhghsat } 0 \\
& \text { 17:26 egnwris a a uf oi } \sim \text {..... t 0;0 pomavs ou }
\end{aligned}
$$

21 Poelman (1965:66) correctly states that these last words of Jesus constitute a summary of his mission: eg nwris a a ut oi" t 0; o homa vs ou (v 26).

22 The fact that the Spirit is not mentioned in the prayer does not imply a denial of the reality and activity of the Spirit in the community. In fact, the Spirit is strongly presupposed in verses 17 and 26. 
life of the disciples. This has, according to Beasley-Murray (1988:483), a variety of implications:

"an ever-increasing understanding of the love of the Father for the Son, an ever fuller grasp of the wonder that love is extended to believers, an ever-growing love on their part to the Father, an ever deeper fellowship with him in the experience of abiding in the Son and he in them. In this way the love command of 13:34 attains its ultimate fulfillment and the prayer of verse 24 its final exposition: the glory of Christ is the glory of God's love. Such is the goal of the history in the new creation brought about by the Son of God ..."

The last phrase, (v 26) kag w; ej a uf oi" , is of great importance to an understanding of the full meaning of the prayer, since it concerns Jesus' abiding (as the glorified Christ) with his disciples. His abiding comes through his word $(8: 31 ; 15: 4,7)$, his Spirit (14:17) (Schnackenburg 1975:225; Barrett 1978:515) and his love (14:23), which also constitute his continuous revelation. Jesus, as we have seen so far, is the mediator of the love of God for the world (3:16) and for the disciples (14:23). But Jesus is also the constant presence of God in the community! Therefore he can continue with his divine revelatory act through his Spirit ${ }^{23}$. In this way he is able to lead his disciples to the fulfilment, the vision of his glory in the heavenly world (Schnackenburg 1975:225; cf. also Bultmann 1941:400).

The fact that God would dwell in the midst of his people was a regular feature of the Messianic hope. But the preposition en (v 26) in this context probably means both 'in' and 'among', referring to the indwelling of God (Christ and the Spirit) in the disciples, and his dwelling among them. The only proper object of the love with which the Father loves the Son is the Son, and it is because he is in the disciples, and in their midst, so that they can be said to enjoy the Father's love (Barrett 1978:515). This will realize when his disciples 'will remain in his word' (8:31), when they

23 Jesus said to them, "Very truly, I tell you, the Son can do nothing on his own, but only what he sees the Father doing; for whatever the Father does, the Son does likewise. The Father loves the Son and shows him all that he himself is doing ...' $(5: 19,20 a)$. Köstenberger points out that this paradigm later became the ruling pattern between Jesus and his disciples (cf. 15:5: '... apart from me you can do nothing.'; 15:15b: '...I have made known to you everything that I have heard from my Father; cf. also 17:6-8, 22, 26). 
'serve Jesus' (12:26), when they 'love one another' (13:34f), and when they 'bear much fruit' $(15: 8)$.

\section{CONCLUSION}

It has been pointed out that a triad of revelation is referred to in 17:24-26: revelation during Jesus' ministry, post-resurrection (realized eschatological) revelation, and future eschatological revelation. Between the first two phases of revelation similarities and differences occur. In both phases the 'name of God' was and will be made known to Jesus' disciples (v 26.1, 2 egnwris a a uf oi" t 0;0homa vs ou kai;gnwrisw). During the first phase of revelation (Jesus' ministry) the disciples' faith was limited to only believing that Jesus 'came from God' (cf. 16:27, 28, 30; 17:8, 25). In the postresurrection phase the Spirit of truth will guide them in all truth (16:13). Then they will be enabled to bear more so that in the end they will believe that Jesus not only came from God, but also went back to God - the message which they have to convey to the world when they will continue Jesus' mission. This completion of the faith-cycle is necessary in order to see and experience the 'glory of the Father' through seeing and experiencing of the glory of Jesus. Faith in Jesus Christ as God's agent and a life of discipleship are required for the future revelation to the disciples. It is only through a love relationship with Jesus (v 26.2) that future (see 13:34f; 17:20-23) and final revelation (Revelatio in Excelsus) can become an eschatological experience (Gloria in Excelsus).

Thus revelation concerns not only the proclamation of knowledge, but also the perception (understanding) and experience of the proclaimed content. For this, faith is needed. Revelation occurs not only on the cognitive level, but also on the affective and experiential levels, and concerns a relationship. Continuous revelation by God is aimed at establishing a continuous relationship dynamic and vice versa. This revelation is a means to an end - that the disciples will see and experience God's glory in and through Jesus' glory in heaven (v 24). Thus verses $25 \mathrm{f}$ serve to ground the eschatological prospect of verse 24. They continue the Father's love for the Son and emphasize the continuing manifestation of the Father to the believers, the continuing 'making known' (gnwrisw) of the Father, in anticipation of the consummation glory (Carson 1991:570). 


\section{Consulted literature}

Barrett, C K 1978. The Gospel according to St John. London: SPCK.

Beasley-Murray, G R 1988. John 13-17: The Community of True Life. Review and Expositor 85, 473-483.

-, 1998 John (Word Biblical Commentary), Volume 36. Dallas: Texas: Word Books, Logos online services.

Bernard, J H 1963. Gospel according to St. John. A Critical and exegetical commentary (Vol 2). Edinburgh: T \& T Clark.

Brown, R E 1972. The Gospel according to John (xiii-xxi). London: Geoffrey Chapman (The Anchor Bible).

Bultmann, R 1941. Das Evangelium des Johannes. Göttingen: Vandenhoeck und Ruprecht.

-, 1971. The Gospel of John (Translated by B Blackwell). Oxford: Basil Blackwell.

Carson, D A 1991. The Gospel According to John. Leicester: Inter-Varsity Press.

Danker, F W (ed) 2000. Greek-English Lexicon of the New Testament and other early Christian Literature. Chicago: University of Chicago Press.

Dodd, C H 1980. The Interpretation of the Fourth Gospel. Cambridge: Cambridge University Press.

Köstenberger, J A 1998. The missions of Jesus and the disciples according to the Fourth Gospel. Grand Rapids: Eerdmans.

Lenski, R C H 1961. The interpretation of St John's Gospel. Utah: Provo.

Lindars, B 1981. The Gospel of John. Grand Rapids: Eerdmans (The New Century Bible Commentary).

Louw, J P \& Nida, E A 1988. Greek-English Lexicon. New York: United Bible Societies.

Malina, B J \& Rohrbaugh R L 1998. Social Science Commentary on the Gospel of John. Minneapolis: Fortress Press.

Malatesta, E 1971. The literary structure of John 17. Biblica 52, 190-214.

Morris, L 1975. The Gospel According to John. Grand Rapids: Eerdmans (The New International Commentary on the NT).

Mundle, W 1978. Revelation in Brown, C (ed). DNTT. Exeter: Paternoster Press.

Newman, B M \& Nida, E A 1980. A Translators handbook on the Gospel of John. London: United Bible Societies.

Nicholson, G.C. 1983 Death as departure. The Johannine descent-ascent schema. Scholars: Chico. 
O'Day, G R 1986. Revelation in the Fourth Gospel. Narrative mode and theological claim. Philadelphia: Fortress.

Onions, C T (ed) 1984. The Shorter Oxford English Dictionary (Vol II). Oxford: Clarendon Press.

Poelman, R 1965. The Sacerdotal Prayer: John XVII. Lumen Vitae 20, 43-66.

Ridderbos, H 1997. The Gospel according to John (A theological commentary). Grand Rapids: Eerdmans.

Sanders, J N \& Mastin, M A 1975. The Gospel According to St. John from Blacks' New Testament Commentaries. London: Adam and Charles Black.

Schenke, 1998. Johannes Kommentar. Düsseldorf: Patmos.

Schnackenburg, R 1968. The Gospel according to St John (Vol 1). London: Burns \& Oates.

-, 1975. Das Johannesevangelium (III Teil). Kommentar zu Kap. 13-21. Freiburg: Hazel.

-, 1988. The Gospel according to St John (Vol 3). London: Burns \& Oates.

Schnelle, U 1998a. Das Evangelium nach Johannes. Leipzig: Evangelische Verlagsanstalt.

-, 1998b. The history and theology of the New Testament writings. Minneapolis: Fortress.

Schwankl, O 1995. Licht und Finsternis (Eis metaphorisches Paradigma in den johanneischen Schrifte). Freiburg: Herder.

Thompson, M M 2001. The God of the Gospel of John. Grand Rapids: Eerdmans.

Van der Merwe, D G 1995. Discipleship in the Fourth Gospel (Unpublished D.D.dissertation), Pretoria: University of Pretoria.

-, 2002. The Glory-motif in John 17:1-5: An exercise in biblical semantics. Verbum et Ecclesia 23(1), 226-249.

Van der Watt, J G 1991. Die Woord het Mens geword: 'n Strukturele uiteensetting van die teologie van die Johannesevangelie, in Roberts J H \& Vorster W S, Vorster J N, Van der Watt, J G 1991 (reds), Teologie in Konteks. Halfway House: Orion, 93-130.

Wilkens, U 1998. Das Evangelium nach Johannes. Göttingen: Vandenhoeck \& Ruprecht (NTD band 4). 